\title{
山形県瀨見産ドレライト及び関聯岩
}

On the dolerite and allied rocks of Semi, Yamagata Prefecture.

$$
\text { 今 } ⿴ 囗 十 \text { 正 (Tadasi Konda)* }
$$

\begin{abstract}
So called "Semi dolerite" is represented by sills and dykes of seven masses. The writer classified those dolerites geologically and petrologically in two groups, namely Semi dolerite and Nagasawa dolerite. Seni dolerite intrudes in the lower part of Nagao formation and the upper part of Semi formation as sill form, but rarely in Nozoki formation in dyke form. Then, Nagasawa dolerite intrudes in the lower part and extrudes in the middle part of Nagasawa formation.

Sills and dykes of Semi dolerite show chilled margins at the lower and upper contact with the intruded sediments. The thickness of the largest sill is 24.4 meters, while its chilled base is 0.8 meters and its upper chilled margin is 0.5 meters thick. When the thickness of sill is over about 20 meters, the petrographyic and chemical compositions vary remarkably from the margins to the central and upper part in one sill, by differentiation "in situ".

The writer found a differentiation sequences in Semi dolerite sill as follows, namely, chilled margins, normal dolerite, felsic dolerite (dioritic layer in the upper part), dolerite pegmatite and granophyric segregation vein. Nagasawa dolerite sills 18.6 meters in thickness, and the grain size is relatively small and uniform throughout the whole body.

As a cilaracteristic nature, it includes numerous xenocryst of quartz, skeleton like plagioclase and hornblende like matters. The chemical composition of Nagasawa dolerite, comparing with the telsic differentiates of Semi dolerite, has the next characteristics: $\mathrm{SiO}_{2}$ component of the latter is equall to the one of the former, while $\mathrm{Fe}_{2} \mathrm{O}_{3}+\mathrm{FeO}$ component is poor, and $\mathrm{Al}_{2} \mathrm{O}_{3}$ and $\mathrm{IgO}$ components are richer in the latter than in the former. Judging from the chemical composition as well as the mineralogical compositions, Nagasawa dolerite is believed to have been derived from the original magma of Semi type dolerite not by the differentiation process, but by the assimilation of the felsic materials as probably the granitic materials.
\end{abstract}

\section{1. 緒晋}

箒者は先に新庄盆地周辺に発達する粗粒玄武岩類（瀬見産粗粒交武岩をふくめて）は地 域性"”をもつことを発表した。その後, 粗粒克武岩のもつとも発達する出羽丘陵中央部 の青沢地域 (庄内盆地東縁部) を調查した結果，これら粗粒菜武岩は泥岩厚層の発婞する

*山形大学文理学部地学教室

1) 今日正：岩鉱, 35, 11 15, 1951 
限られた地筫条件のもとで浅所进入した岩床 (sili)である事が分つた。然し同一地域で

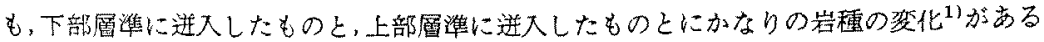

第 1 湿

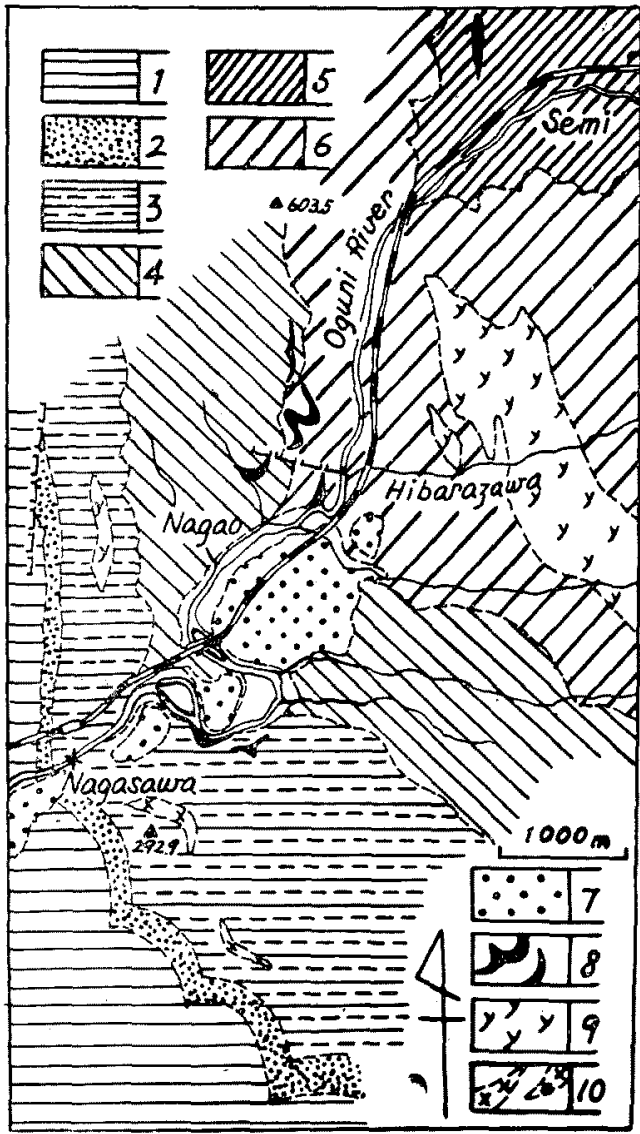

1-井形厤群，2-南沢層，3-長沢層，4-長尾層，

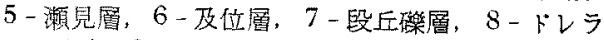
1卜岩床, 9 -流紋岩熔岩, 10 - 玄武岩熔岩
事が分つた。なお，瀨完産 粗粒玄武岩是，同岩の进入 層準より上位にある長沢逆 入岩床とは岩石学的にかな りの相潇が琴的られる。こ の報文は上述 2 岩末の 岩石 学的内容々，进入居準の地 翼学的性格を述べだもで ある。当地の地畨は下位よ り及位尿，瀬見厤，長沢泥 岩層, 骎沢層, 南沢層, 及ひ 舟形層群に分け，粗粒立武 岩の産出地点住第 1 図に， 进入層準は杜状图に，各々 明示してある。最後にここ の研究"1には，小倉勉教徭， 石川依夫教授の御指蓪を戴 き，深謝する次第である。

\section{2. 火山岩の産出状態}

当地の各地層に火山岩が 著しく伴はれる。その産状 の，吟味は層位学的にも又岩 石学的にも，軽視すること の出来ない当のである。次 に各火山岩”の産状につい て述べる。

去武岩 玄武岩は及位層， 瀨見層，長沢層の各鹰に伴 われる。

及位層の芳武岩4 これは もっ上も厚人，150米(+100 愿さで，当地の及位尿の最

1) 今田正：岩鉙, $38,144 \sim 155,1954$.

2) 文部省科学研究費によつて行われた。明記し深謝す。

3) 火山岩の産状は，紙数の関保上，特に瀬見ドレライトに関聯する立武岩，粗粒絔 武岩についてのみ述べた。

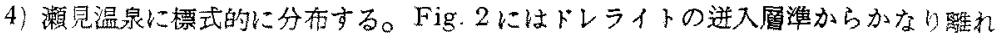
るので一応除いてある。 


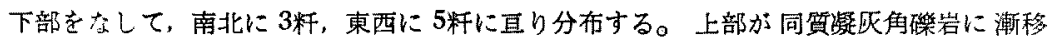
し、 又下部に凝灰岩を介在する点より熔岩流とされる。䕌しい特徴は常に epidotization を受汁，緑籍石が散点状に又は微服を なして，同岩に含まれている。量的に 多い点注目に值する。

瀨晃圈の立武岩は瀬見層の下部に多 く介在吉る。状図（第2图）に示され るように，4枚”含まれる。厚さ 10

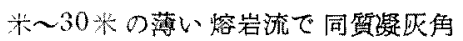

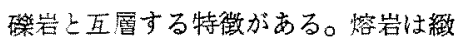
密頃こ下部方稀に集塊岩状を呈する。 分布住小国川より北部に3籸まで追跡 出来るが，更に北部まで延長する可能

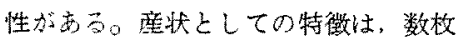
の玄武岩流が同質凝灰角啋岩を介在し て、他の性䁈の火山岩を交えす，一つ の単拉をなて，地層に伴はれる点で ある。岩䝷は詳細にふれないが， $\mathrm{SiO}_{2}$ $=49.12 \%$ の無斑晶輝石立武岩より $\mathrm{SiO}_{2}=57.88 \%$ の安山岩筫支武岩まで ある。变北(alteration) としては石英

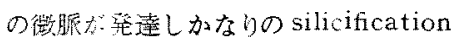
及び chloritization が認められる。こ の変化した無玟晶輝石玄武岩は $\mathrm{SiO}_{2}$ $=57.14 \%$ で $\mathrm{SiO}_{2}$ 量が 8.0296 も增加 する。

曼沢層の去武岩これは先に故大塚 弥之助博士に上り長沢火山岩体”之命 名されだのである。長沢層の中部に 同買岩の 10 程大の角磂を含む㠜灰角

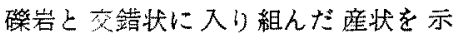
し，又下盤側は集塊岩状及び俵状熔岩 の形態を示し蛻岩流と解される。螾岩 流の厚さは最大 15 米 $(+)$ でかなり厚 く，三论つ熔岩流が略同層淮に発䛭す る。與味ある点はこの玄武岩は融蝕䣄 長石及び石英を含む特徴があり，当地 第 2 図粗粒糹武岩进入関係柱状図

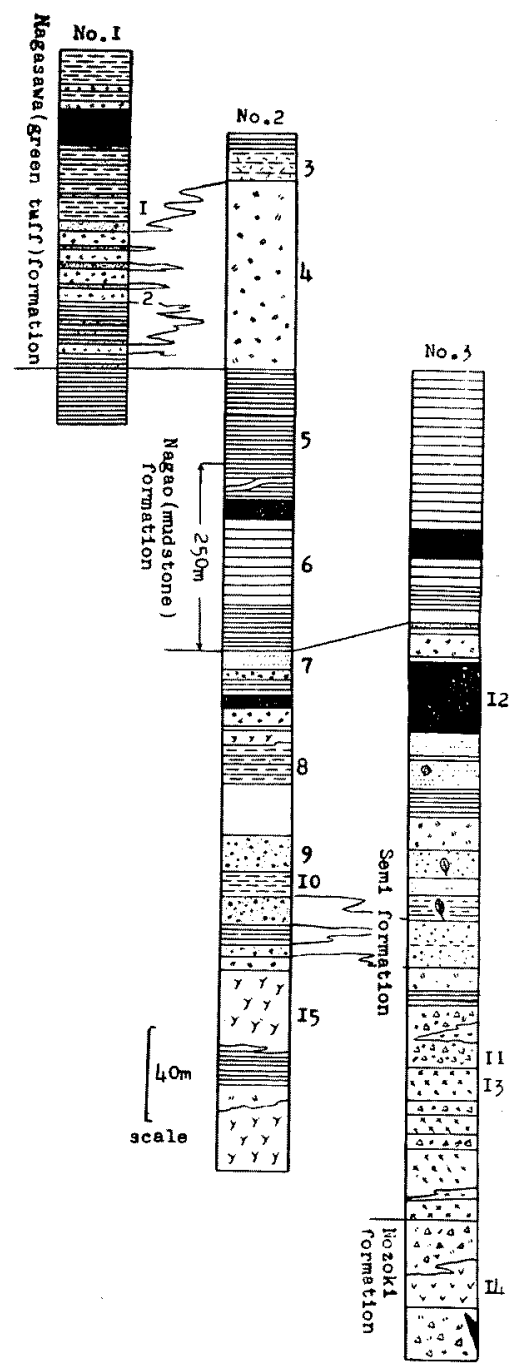
域の他の立武岩と容易に区別出来る。更にこの特徴をもつ玄武岩が熔岩流として入る層

1) 図の外にもう一枚ある。植物化石産出の層準に入る。 
準下約 4 米の位置の㠜灰䁈泥岩，砂岩互層の，加り整層の発達した位置に迸入岩宋と して産出する。このことは出羽丘陵地域における dolerite の basic magma intrusion の迸入時期の上限を示す一資料として貴重なものである。

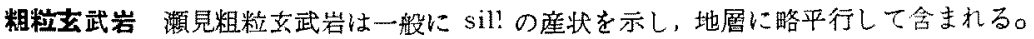
一般に岩床の艮状を示す岩体でも，迸人した岩床と熔岩流として流出した岩床の二種類あ る。本岩の場合は上盤侧をみると，第 3 図のように, ゆるい山凸面を示し，軽度に地層を 切るのが観繁される。又被迸入の堆積岩は著しく黒色化し，更に硬質化するのが普通であ る。瀬見粗粒立武岩は sil1 の厚さ 5 米より 25 米(正確には 24.35 米) まである。延長は 350 米(十)まで追跡される。一般に厚さ大なる程粗粒となり，厚さ薄い場合は去武岩己 粒度、岩石の組織犺同じである。

第 1 表は瀬見粗粒立武岩体の粒度の変化の一例であ

第3図瀨見粗粒立武岩々床

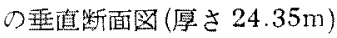

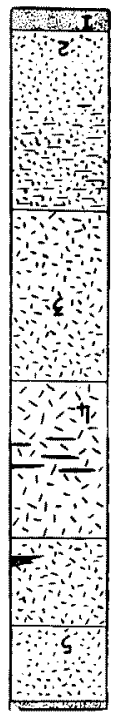

2 relatively pyroxene rich type

3. medium grain type

4. normal dolerite

5. acidic dolerite
1. chilled margins る。この表より迸入体の上盤及ぴ下笽は厚さ50㷧乃至 8「輝の chilled marginsをしめしている。中心部に ゆく程租粒となり，最も粗粒の部分は逤入份の中心上 りやっ上位にある。及そこでは pegmatitic schlieren が岩床括入面に略平行に多数伴つている。

策 1 表 瀨見粗粒去武岩の垂直断面中の最大精度 $(\mathrm{mm})$

\begin{tabular}{|c|c|c|}
\hline & plagioclase & pyroxene \\
\hline $24.1 \mathrm{~m}$ & $\begin{array}{l}0.23 \\
0.88\end{array}$ & 0.11 \\
\hline $22.2 \mathrm{~m}$ & $\left(\begin{array}{l}7.15 \\
1.04\end{array}\right)$ & 0.14 \\
\hline $18.2 \mathrm{~m}$ & $(8.25)$ & 0.83 \\
\hline $15 \mathrm{~m}$ & $\left.\begin{array}{c}2.04 \\
(6.28 \\
0.86\end{array}\right)$ & 3.40 \\
\hline $8 \mathrm{~m}$ & $\begin{array}{c}\left(\begin{array}{c}6.72 \\
0.42\end{array}\right)\end{array}$ & 0.96 \\
\hline $3 m$ & $(6.35)$ & 0.74 \\
\hline $0.5 \mathrm{~m}$ & $\left.\begin{array}{l}0.24 \\
(5.92\end{array}\right)$ & 0.34 \\
\hline contact & $\begin{array}{c}0.16 \\
(3.26)\end{array}$ & 0.08 \\
\hline
\end{tabular}

括孤内は斜長石斑晶の長さを示す。

次に瀬見粗粒立武岩は，当地域内では5岩体がある。 これらは全く同一岩相をもち同一岩然源のものであ る。 5 岩体の迸入層準を前記第 2 図上りみるに，長尾

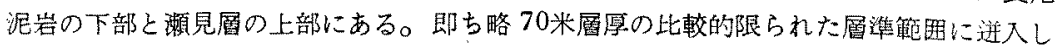
ている。尚及位層中に岩脈状に産出する同岩は，迸入岩獎の通路として，岩床の下位の無 層理凝灰岩の中に岩腿状に入つたものと考えられる。 


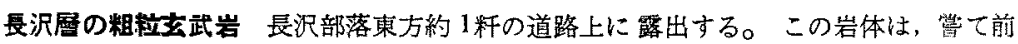
記，長沢火山岩体として記载され，産状は岩脈とされた。然しその産状は下盤側が占路下 の川底に露出し， $\mathrm{N} 80^{\circ} \mathrm{W}, 25^{\circ} \mathrm{S}$ の走向傾斜で露出する，砂岩泥岩互層に，略平行に迸入 している。更に上盤は凝死貿泥岩の層に平行して入つている。然しこの岩体の北側は貫 入状に黑色硬化した泥岩と，急傾斜の角度で接触し，この泡岩を切っている。従つて一部 は岩眼状にも解される1 が全般的にみた埸合は岩床として間違いない。厚さ18.6米で下 盤側はかなり細粓である。更に下盤より4米から8米までは玉娟の1粍乃至に粍大の細服 が略下盤側の面に平行して，多数含まれている。下盤より1(米前後が，かなり粗粒化し，

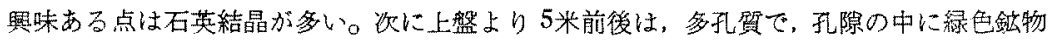

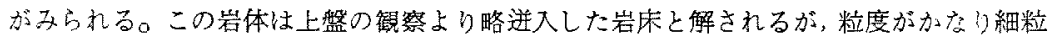
である点，岩石学的の意味では doleriteにできないが，瀨罗粗粒玄武岩のみ括入の亦期

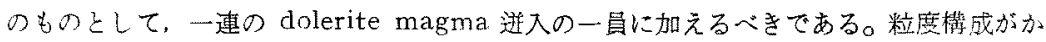
なり細糡なのは， sill の厚さにもよるが，一般に进入層準の上位のものは，末期を代表し， 及进入位置が，早期のものに比し更に地下浅処であるため，一般に細粒化されている。

\section{3. 岩 石記載}

(a) 瀬見トレライト $\left(\mathrm{SiO}_{2}=49.82 \sim 53.56\right)$ 檜原沢対岸の崖に露出する岩体で，上盤 加ら下盤まで筧察される。本岩は既に麾状の項で述へたやうに，㫗さ $24.35 \mathrm{~m}$ を示し，そ の中でfacies の変化がみられる。第 1 表に示される様に粒径も，かなり变化す。興味あ る点は粒垼の变化に伴い組織も変る。即ち周縁部は細粓の閶粒組織を示し，㩖粗粒部(下 部より $15 \mathrm{~m}$ 前後の位置) はオフィテック絽織を示し normal dolerite と无える上半

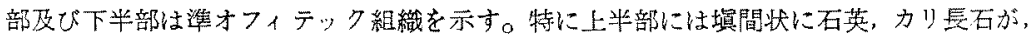

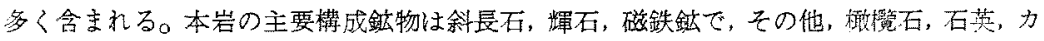
リ長石を少量伴う。灭緑泥石, 橉灰石 (針状結晶) も多く含まれる。斜長石は成分上二種 類ある。即亏 3〜8粍及び $0.5 \sim 1$ 粍大の結晶と $0.1 \sim 0.4$ 粍大の長杜状結晶である。前者 はAn65７0の曹原長石で後者は An 45〜50の中性長石で，明な成分差がみとめられ る。即亏，最粗粒の部分の他は，かなり斑状組織が著しい。輝石は $2 \mathrm{~V}(+)=32^{\circ} \sim 48^{\circ}$ の

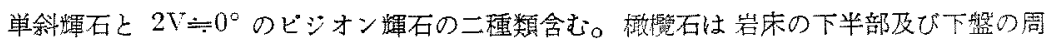
縁相に少量含まれるが殆んど緑泥石に变化している。石英及びカり長石忙岩床中に普遍 的に含まれるが，特に上半部に濃集する傾向がある。又粗䊀の normal dolerite 中では カり長石と石英が徽文象掅造を示して含まれる。磁鉄鉣は，他の榑成鉣物の粒堡の变化と 共に，大きさが変り，周縁相では徽粒であるが，粗粒相では1〜3籷大の結晶として含ま れる。量的にかなり多く未分化の周縁相にも比較的多いのが特徴である。次に、このドレ ライト中で，in situによる分化が行はれ，各種の岩相 (rock facies) を示している。鉴 者は次の 6 facies を諗めた。

(1) chilled margins (2) 輝石の加存り多い部分(下盤接触上り $0.5 \mathrm{~m}$ ) (3) normal dolerite (4) dioritic part (最上部) (5) dolerite pegmatite (6) segregatinn vein 以上の6相である。この rock facies 形成の原因としては，鏡下観察，野外資料上り，堚

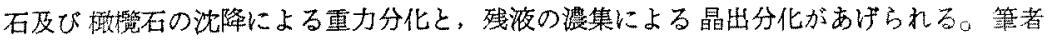

1) 断層の可能性がある。 
第 2 表 瀬見粗䊀玄武岩の化学成分

\begin{tabular}{|c|c|c|c|c|c|c|c|}
\hline & 1 & 2 & 3 & 4 & 5 & 6 & 7 \\
\hline $\begin{array}{l}\mathrm{SiO}_{2} \\
\mathrm{Al}_{2} \mathrm{O}_{3} \\
\mathrm{Fe}_{2} \mathrm{O}_{3} \\
\mathrm{FeO} \\
\mathrm{MgO}\end{array}$ & $\begin{array}{r}50.54 \\
15.24 \\
3.68 \\
6.81 \\
7.12\end{array}$ & $\begin{array}{r}51.84 \\
13.32 \\
4.32 \\
6.67 \\
7.48\end{array}$ & $\begin{array}{r}49.82 \\
14.20 \\
5.86 \\
6.04 \\
6.68\end{array}$ & $\begin{array}{r}53.56 \\
13.42 \\
4.75 \\
6.70 \\
3.78\end{array}$ & $\begin{array}{r}59.14 \\
13.42 \\
4.13 \\
7.81 \\
3.44\end{array}$ & $\begin{array}{r}64.84 \\
11.11 \\
8.04 \\
3.29 \\
1.96\end{array}$ & $\begin{array}{r}53.76 \\
15.92 \\
4.09 \\
3.86 \\
5.36\end{array}$ \\
\hline $\begin{array}{l}\mathrm{CaO} \\
\mathrm{Na}_{2} \mathrm{O} \\
\mathrm{K}_{2} \mathrm{O} \\
\mathrm{H}_{2} \mathrm{O}(+) \\
\mathrm{H}_{2} \mathrm{O}(-)\end{array}$ & $\begin{array}{l}7.78 \\
2.69 \\
1.05 \\
1.26 \\
1.78\end{array}$ & $\begin{array}{l}8.62 \\
3.25 \\
0.40 \\
1.56 \\
1.86\end{array}$ & $\begin{array}{l}8.52 \\
2.76 \\
0.83 \\
1.07 \\
1.98\end{array}$ & $\begin{array}{l}7.88 \\
3.26 \\
0.89 \\
1.34 \\
2.18\end{array}$ & $\begin{array}{l}5.12 \\
3.49 \\
1.61 \\
0.24 \\
0.56\end{array}$ & $\begin{array}{l}4.74 \\
3.58 \\
1.72 \\
0.18 \\
0.86\end{array}$ & $\begin{array}{l}7.84 \\
2.24 \\
0.67 \\
1.48 \\
2.86\end{array}$ \\
\hline $\begin{array}{l}\mathrm{TiO}_{2} \\
\mathrm{P}_{2} \mathrm{O}_{5} \\
\mathrm{MnO}\end{array}$ & $\begin{array}{l}1.48 \\
0.11 \\
0.23\end{array}$ & $\begin{array}{l}0.76 \\
0.26 \\
0.13\end{array}$ & $\begin{array}{l}1.65 \\
0.32 \\
0.25\end{array}$ & $\begin{array}{l}0.60 \\
0.48 \\
0.18\end{array}$ & $\begin{array}{l}0.94 \\
0.22 \\
0.17\end{array}$ & $\begin{array}{l}0.33 \\
0.18 \\
0.13\end{array}$ & $\begin{array}{l}0.42 \\
0.10 \\
0.13\end{array}$ \\
\hline Total & 99.77 & 100.47 & 99.98 & 99.02 & 100.29 & 100.96 & 98.73 \\
\hline
\end{tabular}

1. Lower contact of Semi dolerite

2. $05 \mathrm{~m}$. point from lower contact

3. $15 \mathrm{~m}$. point from lower contact

4. $23.4 \mathrm{~m}$. point from lower contact

5. Dolerite pegmatite at $18 \mathrm{~m}$. point from lower contact

6. Segregetion vein (granophyric) at $16 \mathrm{~m}$. point from lower contact

7. Nagasawa dolerite

は、この各岩相の岩片の総化学成分より, 各酸化物の变化の傾向を調へた。即ち, 第2表 1.2.3.4.5. の分析值より，その傾向を求めると，次の点があげられる。 (a) $\mathrm{SiO}_{2}$ 成 台は normal doleriteでは侐か減少するが, dioritic partで 396, pegmatiteで 9\%, segregation vein では 1496 堌加する。 (b) $\mathrm{Al}_{2} \mathrm{O}_{3}$ 成分は漸次減少するが, segregation vein では約 4\%減少する。 (c) 鉄成分は漸移的に壃加するが, segregation vein において $1.7 \%$ 増加し，その濃集の程度弱い特徴がある。 で大で，分化の進むに帡い著しく減少する。(e) CaO 成分は，僅少增加するが，pegmatite 及ぴ segregation vein では急激に減少する。 (f) アル力リ成分は, や>増加 する。以上の点が要約されるがこの傾向を $\mathrm{Fe}_{2} \mathrm{O}_{3}+\mathrm{FeO}-\mathrm{MgO}-\mathrm{Na}_{2} \mathrm{O}+\mathrm{K}_{2} \mathrm{O}$ 三角図 表によつて現すと，Tasmania 産トレライトの分化 ${ }^{1 ”}$ と類似する。特徴的に，鉄成分の 濃集は著しくない。

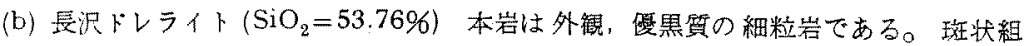
織を呈す。構成銥物は，斜長石，単斜輝石を斑晶として含み，石基は斜長石，単斜輝石，

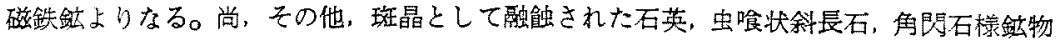

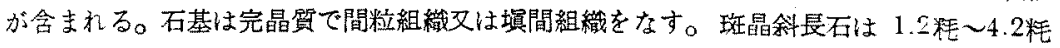
大で，譬開の著しい短壮状結晶である。注目すべき点は、この斜長石は大部分が融蝕を

1) Edward, A. B. : Jour. Geol,, 50, 1942 
うけ，結晶内部に点滴状玻琌ができ，虫飡い状を呈している。又外㲄に新鮮な斜長石を伴 い，一檑の罢带棈造を示している。内部は An 46〜50 $\left(\mathrm{n}_{D}=1.552 \sim 1.556\right)$ 外部は An 52〜60 ( $\left.\mathrm{n}_{D}=1.557 \sim 1.561\right)$ で成分上，著しい差はない。石基中の斜長石は $0.1 〜$ 0.3 粇大，自形性の強い，短性状結晶で An 59 64 $\left(\mathrm{n}_{D}=1.560 \sim 1.564\right)$ の曹灰長石 である。徥つて斑晶石基間の成分差は殆んどない。単斜輝石は斑晶としては，量が少く， 殆んど0.1〜0.6粍大の，吕なり自形性の強い結晶として大部分石基に多く含まれる。斑 晶さ存本ものは， $\alpha=1.685 \sim 1.6902 \mathrm{~V}(+)=60^{\circ} \sim 62^{\circ}$ の普通輝石で，石基中のものは $2 \bigvee(ケ)=34 \sim 37^{\circ}$ のビキオン質輝石である。及，石英の周りに密集する反応縁の輝石は

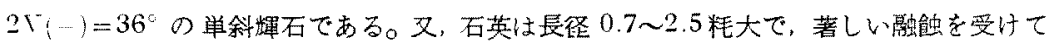
いる。結晶内部に，includeする鉱物はないが，結晶内部にできた，割目に沿い玻㴬が発 達する。一般に普通輝石の反応䋑をもつ。次に斑晶大の鉣物でかなり長柱状の鉱物が，緑

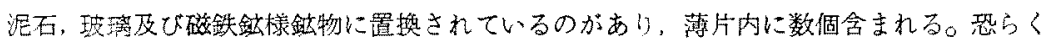

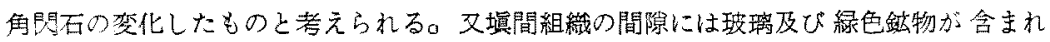
る。上述記載よりみると，本岩はや〉玟状のソレアイト立武岩で，外来結晶を伴うもので あると云い得る。

なお，化学組成（第2 表7）は䈏て，故杉健一教授が研究された，山口県荻市䈉山の石

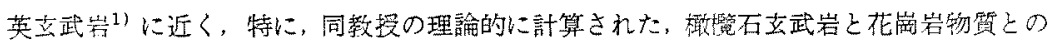

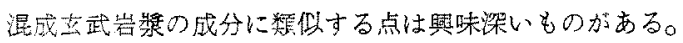

\section{4. 考察}

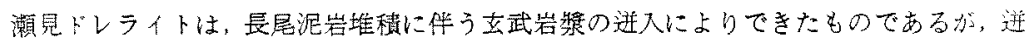
入屡準に汃なりの距離をもつて，長沢ドレライトの进入か゚みられる。これは野外地䓄より みて前者力逆入に徭統し，更により浅姏に逆入したものと考えられる。一般に出羽丘陵地 域で、ドレライトが薄い岩床を示す場合，岩脈に入つている場合，及は一連の进入岩床の 中で最上部のもの等では，典型的な ophitic texture 示さないことが多い。然し，同 じ地䁈関壆の中で，同一地域に於いて一連の迸入岩床を示す場合は，何等かの成因闂係を もつと考えられる。本報文の瀬見及び長沢のドレライトも亦そうである。長沢ドレライ 卜は瀬是に比し, $\mathrm{SiO}_{2}$ 量多く acid type ${ }^{21}$ とされる。従つて, 若し前者が後者上り岩漿 分化によつて成生されたならば, 両者の間に，構成鉱物の種類及びその性質，㕛は化学成 分上より何等かの関係をもたなければならない。然るに，構成鈜物を此較すると，長沢卜 レライトは外来源とされる石英, 角閃石様物質を含むと云う特徽の外に, 瀬見ドレライト の分化の末期を代表する pegmatite, segregation vein (granophric) 及び sill の上部 にみられる dioritic layerに多くでる，kalifeldsparを全く含まない。更にトレライト の分化の進むに従い, felsic mineral が減少し, 逆に quartz, kalifeldpar 等が 約6 10\%に增加する。一方，長沢ドレラィト中の充填状石英及び玻离は2〜4\%に過ぎない。 構成鉱物の性覧として，石基中の斜長石は，密る長沢トレライトの場合が calcic type である。化学成分上よりみると， $\mathrm{SiO}_{2}$ 成分は瀬見トレライトの dioritic layer 第 3 表

1) 榇健一：九大理研究報告，3，昭 26.

2) 分化の尺度として $\mathrm{SiO}_{2}$ 量をもつてすることは，必すしも適当に考えられないが， 従来の概念の下で説明を進めることにする。 
4)に近い。 $\mathrm{Al}_{2} \mathrm{O}_{3}$ 成分は chilled marginよりもや〉多く，更に分化の進んだもよ りは，かなり多くなる。鉄成分は著しく少ない。 MgO成分は chilled marginより少 いが，分化の進んたもものりは比較的大である。 $\mathrm{CaO}$ 成分は，著しい相違はないが， pegmatite 及び segregation vein 中のものに比較すると，功り多い。アルカリ成分 は chilled margin と略々同じであるが，分化の進んだものに比較すると少い。以上の各 性留をみると，長沢ドレライトは，総ての点で瀬見ドレライトの岩漿分化によつて出来た と考え難いものがある。恐らく瀕見ドレライト岩墏に花崗岩貿物筫の同化により長沢ドレ ライトが生成されたものと考えられる。最後に，簡単にのべると、トレライトは出羽丘陵 のみならず東北地方に広範囲に分布し，各種の岩型を示している。筆者は現在の段階で， 8種類認めている。これ等は，岩型と云うより，東北地方に於ける一連の火成活動を示す ドレライト岩漿の岩種 (rock species) としたい。岁岩型にみら礼る in situの分化産物 山岩相 (rock facies) とされる。この岩相と岩稙の間に，どう云う成因関係があるか，充 分积討される心゙き問題である。これは，トレライト岩獎迸入の地質条件の解析と，各岩体

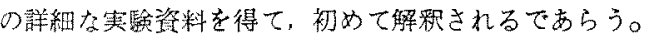

\section{鳥ノ巣統砂岩の耐圧強度と彈性係数の測定について}

On the measurements of the bearing-power and the modulus of elasticity of sandstone in the Torinosu series.

\section{倉 持 文 雄 (Fumio Kuramochi)*}

1. 要旨

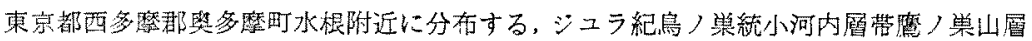

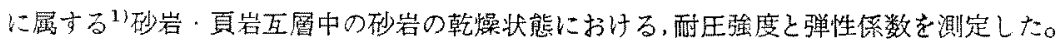
また前記の測定にあたつてあらかじめ見掛け比重・吸水率・有孔率等も測定した。そ

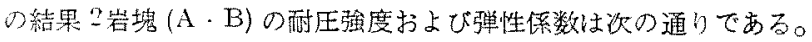

\begin{tabular}{|c|c|c|c|c|c|}
\hline$\frac{1}{2}$ & $\frac{\text { 酎圧䧺度 }}{\mathrm{kg} / \mathrm{cm}^{2}}$ & $\begin{array}{c}\text { メング率 } \\
\mathrm{D} / \mathrm{cm} 2 \times 10^{11}\end{array}$ & ポア & $\begin{array}{l}\text { 体積弹性率 } \\
/ \mathrm{cm} 2 \times 10^{11}\end{array}$ & $\begin{array}{c}\text { 㓮性率 } \\
\mathrm{D} / \mathrm{cm}^{2} 2 \times 10^{11}\end{array}$ \\
\hline A & $2,681.3 \sim 3,447.3$ & $6.5 \sim 7.8$ & $0.22 \sim 0.27$ & $4.1 \sim 5.3$ & $2.6 \sim 3.1$ \\
\hline B & $2,605.6 \sim 3,160.0$ & $6.2 \sim 10.1$ & $0.1 E \sim 0.33$ & $3.5-6.8$ & $2.5 \sim 4 . \pm$ \\
\hline
\end{tabular}

\section{2. 甋 料}

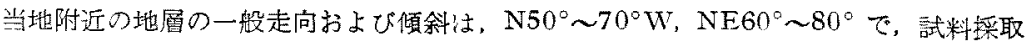

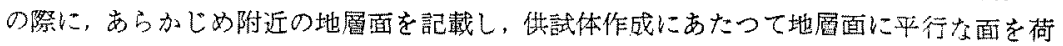
重面とするようにした。

径約 $30 \mathrm{~cm}$ の砂岩塊を 2 個 (A.B) 採取し，それぞれ $5 \mathrm{~cm}$ 立方状㤨試体を 4 個ずつ棓

* 東京都水道局小河内眝水池建設事務所

1) 藤本治義: 関東の地啠，45～50，1932，秩父多摩国立公園の地货，6９，1953 関東地方一日本地方地質誌，17～19，1953 